\title{
FROM BOYS TO MEN IN EDWARD BULWER-LYTTON'S PELHAM AND HORATIO ALGER'S STRUGGLING UPWARD: THE DANDY AND THE SELF-MADE MAN COMING OF AGE
}

\author{
MARTA MIQUEL BALDELLOU \\ Universidad de Lleida
}

\section{Resumen}

En la Inglaterra victoriana y la América decimonónica, las narraciones de aventuras se convirtieron en un género privilegiado para inculcar determinados valores a los chicos jóvenes. A pesar de la supuesta universalidad que suele caracterizar a estos relatos, las concepciones de nación y género que presentan suelen caracterizar a sus países de origen. El escritor inglés de la época victoriana Edward Bulwer-Lytton, en su temprana novela, Pelham (1828), retrata el paso del joven protagonista hacia la madurez mientras adquiere los valores socialmente acceptados en el periodo victoriano. Al otro lado del Atlántico, Horatio Alger favoreció la creación del 'sueño americano' a través de novelas como Struggling Upward (1890), describiendo a jóvenes convertiéndose en hombres hechos a sí mismos. Este artículo tiene como objetivo analizar cómo las concepciones transatlánticas de nación y masculinidad se construyen en ambas novelas.

Palabras clave: bildungsroman; aprendizaje; nación; masculinidad; el dandi; el hombre hecho a sí mismo; Inglaterra victoriana; América decimonónica; transatlanticismo; Edward Bulwer-Lytton; Horatio Alger.

\begin{abstract}
In Victorian England and 19 ${ }^{\text {th }}$ century America, adventure stories became a privileged genre to inculcate young men certain values. Despite the pledged universality of these stories, the conceptions of nation and gender present often characterise their country of origin. The English Victorian writer Edward Bulwer-Lytton, in his early novel, Pelham (1828), portrays the young protagonist's journey towards maturity while displaying the values socially sanctioned in Victorian times. On the other shore of the Atlantic, Horatio Alger instigated 'the American dream' through novels such as Struggling Upward (1890), depicting young boys in their adventurous path towards becoming self-made men. It is the aim of this article to analyse how transatlantic conceptualisations of nation and masculinity are constructed in both novels.
\end{abstract}

Key words: bildungsroman; apprenticeship; nation; masculinity; the dandy; the self-made-man; Victorian England; 19th-century America; transatlanticism; Edward Bulwer-Lytton; Horatio Alger. 
$\mathrm{T}$ he Victorians became fairly concerned with the process whereby one stopped being a child and became an adult. The term 'adolescence' came into vogue in the nineteenth-century and adolescents, despite being regarded as different from children or adults, were inculcated the Victorian notions of what it meant to be an adult so as to attain "one's capacity for intellectual, emotional, and moral development" (Vanden, 2005: 83). As Chris R. Vanden remarks, "arriving at adulthood meant not just coming of age, but developing a particular kind of self" (2005: 82). In the Silver-Fork genre that arose in mid-nineteenth-century England, the Victorian writer Edward BulwerLytton not only initiated the genre but also contributed to portraying the 'coming of age' of young individuals in society through the introduction of the dandy as a national figure of the time.

The dandy in Victorian literature aimed at imitating an aristocratic lifestyle, even though some of them came from common backgrounds. Clinging to feudal or pre-industrial values, dandyism implied a non-political protest against the rise of egalitarian principles and the emerging classes that menaced to counteract the aristocracy. Historically, the figure of the dandy originated in the revolutionary 1790s, especially in London and Paris, and was deemed to elevate aesthetics to a living religion, placing particular importance upon physical appearance, refined language, and the cultivation of leisurely hobbies, that is, he often came of age through social sanction (Glick, 2001: 129-163; Goldfarb, 1962: 369-373; Lane, 1994: 29-52; Rossbach, 1999: 81-102; Saisselin, 1956: 457-460; Spence Smith, 1974: 725-743). The very model of the dandy in British society was George Bryan 'Beau' Brummell; although other well-known early dandy figures of the period were the Count d'Orsay, George Gordon Lord Byron, and Edward Bulwer-Lytton, whose popular novel Pelham (1828) carefully depicted and sanctioned the dandy as one of the main characters in nineteenth-century England. In addition, Pelham is considered one of Bulwerlytton's most popular apprenticeship narratives (Campbell, 1986: 22-37) as well as the novel that inaugurated the silver-fork genre in England (Hugues, 1992: 328-347; Cronin, 2004: 38-53).

On the other shore of the Atlantic, juvenile nineteenth-century narratives addressed young male readers depicting heroes who succeeded in seeking fortunes to become self-made men through their process of coming of age. This spirit of successful initiative individualism was rooted in the American nation. Since its origins, the policy of the British settlers was to create "institutions that left the actual settlement process to private individuals to seek out the capital and the labor to be used in conjunction with the land and resources in the Americas" (Engerman and Gallman, 2006: 121).

The figure of the self-made man is inextricably linked with the American Dream. Benjamin Franklin, one of the Founding Fathers of the United States, was deemed to have created the archetype in his own Autobiography. (Franklin, 1999: 223-285). The self-made man is that who, coming from low origins and against all odds, climbs up the social ladder, achieving a comfortable social position which harshly contrasts with his humble origins. Key factors in rag-toriches tales are hard work, solid moral foundation, and self-improvement. As 
opposed to the inheritance system that was sanctioned in Europe due to monarchic systems based on birth rights, the self-made man does not inherit his social position by birth, but rather succeeds without outside assistance. It is not luck who makes the self-made man, but he rises in the social ladder through hard work, perseverance and resolution. It is the necessity that characterises low origins which challenges the humble man to rise up and become a successful self-made man. This character is deeply ingrained in the American culture, where belief in the ability to move between social classes is an important part of national identity. The rag-to-riches stories are meaningfully absent in societies with a rigid hierarchical social system. Horatio Alger was mainly responsible for popularising narratives, addressed to young men, featuring a hero from low origins who, despite the difficulties, managed to climb up the social ladder to reach a flamboyant position in the American society.

Bulwer-Lytton's Pelham depicts the process whereby Henry, a young man belonging to the English nobility, leaves his adolescence behind and enters into maturity. Henry proves well-aware of the importance of family origins and class assumptions by stating:

I am an only child. My father was the younger son of one of our oldest earls, my mother the dowerless daughter of a Scotch peer. Mr. Pelham was a moderate whig, and gave sumptuous dinners; - Lady Frances was a woman of taste, and particularly fond of diamonds and old china. (Bulwer-Lytton, 1848: 1)

Next to family origins and social class, academic education proves of primary importance. At the age of ten, Henry begins his academic instruction at Eton, where he displays his refined tastes "for refusing, with all the pride of a Pelham, to wash tea-cups" (Bulwer-Lytton, 1848: 3). It is also at Eton that Henry makes his first acquaintances, only with the most prestigious embodiments of the English society, such as Reginald Glanville, the son of "a baronet, of a very ancient and wealthy family" (Bulwer-Lytton, 1848: 3). Since Henry's father is seriously ill, it is his mother, Frances, who supervises his son's coming of age in society. ${ }^{1}$ Through her letters, Frances reminds Henry of his social position and recommends him to be very careful in choosing his acquaintances, stating: "Remember, my dear, that in all the friends you make at present, you look to the advantage you can derive from them hereafter" (Bulwer-Lytton, 1848: 3).

Once he leaves Eton, Henry must resort to establishing social relations, and so he accepts the invitation of Sir Lionel Garrett to visit him at his country estate. As Henry claims, Sir Lionel "was a character very common in England, and, in describing him, I describe the whole species. He was of an ancient family, and his ancestors had for centuries resided on their estates in Norfolk" (Bulwer-Lytton, 1848: 5). It is also at Garrett Park that Henry becomes firstly acquainted with one of the most promising candidates for a prospective

\footnotetext{
${ }^{1}$ There is a remarkable resemblance between the mother-son relationship established between Frances and Henry in Pelham, and the real-life mother-son bond between Elizabeth Barbara Bulwer and Edward George Bulwer-Lytton. By extension, Henry Pelham bears a strong resemblance with the author himself.
} 
marriage, Lady Roseville. Henry soon tries to gain her favours, roused by his mother's advising sentence: "Nothing, my dear son, is like a liaison (quite innocent of course) with a woman of celebrity in the world" (Bulwer-Lytton, 1848: 9). While Henry pursues these romantic endeavours, the guests at Garret Park showed their fondness of sports such as shooting. Nonetheless, it is at these displays of physical energy that Henry unveils the delicacy and effeminacy of the dandy, stating

\begin{abstract}
Seriously, that same shooting is a most barbarous amusement, only fit for majors in the army, and royal dukes, and that sort of people; the mere walking is bad enough, but embarrassing one's arms, moreover, with a gun, and one's legs with turnip tops, exposing oneself to the mercy of bad shots and the atrocity of good, seems to me only a state of painful fatigue, enlivened by the probability of being killed. (Bulwer-Lytton, 1848: 12)
\end{abstract}

After leaving Garret Park, Henry is initiated in coming out at balls. It is there the appropriateness of fashion proves of primary importance. Henry sarcastically reflects on the necessity to accept fashion dictates despite their artificiality claiming that:

Fashion with us is like the man in one of Le Sage's novels, who was constantly changing his servants, and yet had but one suit of livery, which every new comer, whether he was tall or short, fat or thin, was obliged to wear. We adopt manners, however incongruous and ill suited to our nature, and thus we always seem awkward and constrained. (Bulwer-Lytton, 1848: 12)

Thus, after a brief stay in London, Henry travels to Paris in order to pursue his social formation. Actually, he travels with a purpose in mind: "to set up 'a character;' for I was always of an ambitious nature, and desirous of being distinguished from the ordinary herd" (Bulwer-Lytton, 1848: 20). Henry devotes much time to dressing up before coming out at a ball, although he is careful not to betray his concern:

I arranged my hair into ringlets, dressed myself with singular plainness and simplicity (a low person, by the by, would have done just the contrary), and, putting on an air of exceeding languor, made my maiden appearance. (BulwerLytton, 1848, 20)

Throughout the dinner, Henry is well-aware of his good looks, and is no hesitant at showing his conceit when coming back home musing to himself: "I was perfectly satisfied with the effect I had produced [and] conscious, as the wind waved my long curls, that I was looking to the very best advantage" (Bulwer-Lytton, 1848: 21). It is after Henry's coming out that his mother sanctions his initiation concluding he has "now fairly entered the world" (Bulwer-Lytton, 1848: 23). Henry's conceit is also shown in his regard for exuberant ladies who soon fall into oblivion once he has managed to draw their attention to him. 
While Henry learns the importance of fashion to excel in social endeavours, he also reflects on the importance of manners to interact in society, stating that it is "better for a man to possess them, than wealth, beauty, or even talent [...] [since] they will more than supply all" (Bulwer-Lytton, 1848: 29). Next to a faultless appearance and exquisite manners, the art of conversation proves crucial to succeed in social endeavours. Henry takes well care of improving his French accent and proves well-versed in the literary tastes of the time, as well as in the classic authors as a result of his conscientious education.

In addition to attending balls and operas, the pursuit of coming of age in society cannot be completed without proper instruction as to how to proceed at duels. Despite Henry's partiality to shooting as a sport, he resorts to action at the first signal of offence. Nevertheless, although roused to action, Henry approaches his rival "with the utmost calmness and composure" (BulwerLytton, 1848: 26).

Once Henry has taken "the greatest pains to complete [his] education" (Bulwer-Lytton, 1848: 48) he receives a letter from his mother in which she urges his return to London, where he will engage in his professional career, aided by valuable connections. After his formation in Paris, Henry becomes fully aware of the intricacies of English society in which he will become a representative citizen, as he shows in a monologue that is worth quoting since it outlines the precepts that define the gentleman, which basically amount to conforming to social requirements:

\begin{abstract}
I saw that the character of the more fashionable of the English was servile to rank, and yielding to pretension - they admire you for your acquaintance, and cringe to you for your conceit. The first thing, therefore, was to know great people the second to control them. I dressed well, and had good horses - that was sufficient to make me sought by the young of my own sex. I talked scandal, and was never abashed - that was more than enough to make me admired the matrons of the other. It is single men, and married women, to whom are given the St. Peter's keys of Society. I was soon admitted into its heaven - I was more - I was one of its saints. I became imitated as well as initiated. (Bulwer-Lytton, 1848: 87)
\end{abstract}

Thus, social position, academic instruction, important acquaintances, travelling, fashion and appropriate manners, but resolute action at duelling are the distinct traits that characterise Pelham, and by extension, the gentleman. However, in addition to these traits which also describe the aristocrat, Henry is well-aware of the need to adapt to the changes of Victorian society. Despite his conceit and, at some points, overwhelming ostentation, he is also critical of them. As he grows up, properly instructed by his uncle, Henry reflects on the importance of education, the necessary alliance between public policy and private morality and the transcendence of true love. Thus, Henry indulges in fashionable life, but his moral instruction is never left unattended. As he claims, "I am perhaps less ignorant than I affect to be: it is now my object to be a dandy" (BulwerLytton, 1848: 112). Gradually, he grows tired of social gaieties, however, his distinction, far from decaying, even excels. As he admits, 
I shrank, by rapid degrees, into a very small orbit, from which I rarely moved. I had already established a certain reputation for eccentricity, fashion, and, to my great astonishment, also for talent, and my pride was satisfied with finding myself universally run after, whilst I indulged my inclinations by rendering myself universally scarce. (Bulwer-Lytton, 1848: 122)

Thus, Henry is able to reach a balance between his fashionable life and his moral and intellectual integrity. He gradually becomes dissatisfied with the glittering of social gatherings, although he never neglects them completely, and becomes more engaged in his preparing for engaging in the law profession.

Thus, in a broader context, as a reflection of the period, Bulwer-Lytton had also evolved in the depiction of his own characters. In Pelham, the novel that inaugurated the Silver-Fork genre, Henry is the prototype of the English dandy, deeply rooted in his aristocratic origins, but inevitably acknowledging the arising importance of the emerging bourgeoisie. As Oakley assumes, Pelham "incorporates the dandy ethic with, other contrasting components" (1992: 50), as a reflection of the changes in the period when there was "an 'abdication' of the aristocracy and gentry in favour of groups more suited to the time" (Oakley, 1992: 49). Thus, "the hero is both exemplary of the dandy ideal but also critical of existing dandyism" (Oakley, 1992: 50). The historical changes in Victorian society are those reflected in the process of maturation Henry undergoes. In the preface to the 1828 edition of Pelham, Bulwer-Lytton (1848: vi) claimed

[he] had drawn for the hero of [his] Work, such a person as seemed to [him] best fitted to retail the opinions and customs of the class and age to which he belongs; a personal combination of antitheses - a fop and a philosopher, a voluptuary and a moralist - a trifler in appearance, but rather one to whom trifles are instructive.

Thus, Bulwer-Lytton aimed at drawing a faithful portrait of the gentleman of the English society of his time. Subsequently, in the preface to the 1840 edition, he justified his endeavour stating that "the lessons of society do not necessarily corrupt, and that we may be both men of the world, and even, to a certain degree, men of pleasure, and yet be something wiser-nobler-better" (BulwerLytton, 1848: viii). Moreover, it was in the 1848 edition that Bulwer-Lytton realised Pelham was the portrait of a past life, thus acknowledging that the novel

is the picture of manners in certain classes of society twenty years ago, and in that respect I believe it to be true and faithful. Nor the less so, that under the frivolities of the hero, it is easy to recognise the substance of those more serious and solid qualities which Time had educed from the generation and the class he represents. (Bulwer-Lytton, 1848: xv)

In nineteenth-century America, Horatio Alger portrayed how young heroes prospered both economically, but also morally, through their process of ageing into adulthood (Zuckerman, 1972: 191-209). At a time when the popular manual of conducts and the dime novels emerged, Alger wrote more than a hundred novels from 1867 to 1899, through which he depicted optimistic and enterprising individuals facing their growing in a disrupted family and 
problematic financial circumstances. In a way, he was constructing the American enterpreneur character (Pitofsky, 1998: 276-290). As Cail Bode claims, at the same time Horatio Alger "was telling a troy to enthral the boys, [he was also] preaching a Protestant ethic endorsed by their parents" (1985: x) Although coincidence and good fortune always play an important role to enact the heroes' rising from rags to riches, the young men must be endowed with certain values such as honesty, respectability and temperance. Among all his heroes, the Ragged Dick series became the most popular. Nevertheless, towards the end of his career, in 1890, Alger published Struggling Upward, which proved quite acceptable to his readers and displayed the author's time-tested formula from the title page to its conclusion.

In Struggling Upward, the young hero, Luke Larkin, is the dutiful son of a carpenter's widow, who lives "on narrow means, [and is] compelled to exercise the strictest economy" (Alger, 1985: 135). In order to make a living for his family, Luke works as a janitor at the school he attends. Despite his financial difficulties, Luke always "had a pleasant expression, and a bright, resolute look, a warm heart, and a clear intellect, and was probably, in spite of his poverty, the most popular boy in Groveton" (Alger, 1985: 136). As a counterpart to Luke, Randolph Duncan, the son of the president of the Groveton Bank, is described as a young aristocrat, self-conceited and deceitful. Despite his contrasting flamboyant position, Randolph envies Luke and deeply resents the fact that Luke is so well-considered and skilful despite his humble origins.

Rivalry and competition prove constant challenges for the individual's display of strength and resistance. In the episode of the skating race, Luke and Randolph contend for victory. Randolph, well-aware that his chances to beat Luke are scarce, decides to convince Tom to get into Luke's way during the race. Despite Randolph's victory over Luke, all the boys know of Randolph's machinations and so his victory proves to no avail. Alger underlines that honesty proves a more important value than success through deceit. Moreover, as a result of his victory, Randolph receives a watch, despite the fact he already has a more valuable one. Consequently, Tom demands from him the watch as a reward for having helped him beat Luke in the race. Randolph absolutely refuses to reward Tom for his contribution. Thus, Randolph proves both corrupt and ungrateful. By contrast, Luke clearly remarks that he wanted to win the race in order to be regarded as the best skater. Moreover, as regards the prize, Luke would have liked to gain the watch in order to show it to his mother as any dutiful son would do. Throughout the novel, it is implied that Luke's relation with his mother is one of love and support, whereas Randolph only seems to praise his father for his economic status.

In any case, Luke is never pessimistic, but rather self-reliant, very confident and extraordinarily enthusiastic in order to face different ordeals. Luke's confidence and resilience shine over the expensive and smart suits that Randolph wears at Florence Grant's birthday party. It is during the previous moments of the party that we become aware of Luke's physical growing up matches his maturation towards adulthood, as it is stated that "during the past year Luke had grown considerably, and his coat-sleeves were nearly two inches 
too short, and the legs of his trousers deficient quite as much" (Alger, 1985: 152). Nevertheless, Luke is not concerned about it since he states "Florence didn't invite me for my clothes" (Alger, 1985: 153). At the party, it is snobbish Randolph who refers to Luke's appearance and states "any other boy would be ashamed to come to a party in such ridiculous clothes" (Alger, 1985: 155). However, everybody dismisses his remark once Florence greets Luke and his friend Linton with unaffected cordiality. Moreover, Luke gradually becomes a proficient dancer and a frequent companion of Florence on the dance floor. Subsequently, as a result of envy, Randolph decides to convince his father, who is in the school committee, to dismiss Luke as school janitor. Luke proves his inestimable value by even offering himself to instruct the new janitor in his job. Moreover, instead of falling into acute hopelessness, he is confident and avoids upsetting his mother asserting he is "sure something will turn up in its place" (Alger, 1985: 165).

Despite many difficulties and sufferings, there is always a turning point in the lives of Alger's heroes. As described in Struggling Upward, "it was a commonplace errand, that on which Luke had started, but it was destined to be a very important day in his life. It was to be a turning-point, and to mark the beginning of a new chapter of experiences" (Alger, 1985: 146-7). Providence and good fortune are always present in the career of the self-made man. However, it is often interpreted as a reward for goodness and honesty. A stranger, subsequently known as Roland Reed, approaches Luke in the street and asks him to keep a tin box with unknown contents until he returns to the neighbourhood. In exchange, Luke is given some money which, instead of spending, he decides to save. Subsequently, the bank safe is robbed and one of the tin boxes is reported to be missing. Miss Sprague, knowing Luke is in possession of a similar tin box, decides to inform the bankers. As a result Luke is arrested for his loyalty to Roland Reed when he made the promise to keep his tin box. Once he is arrested, Luke has faith in himself since he knows he is innocent and he appeases his mother stating "we both know that I am innocent, and I rely on God to stand by me" (Alger, 1985: 180).

It is at this juncture that the owner of the tin box returns to release Luke from prison. Roland Reed proves a proper benefactor to Luke and initiates him in the ways of the world. Roland tells Luke about his youth as a California miner. He instructs Luke as to what is proper according to age, and how travelling and rough work characterise youth since "boys like nothing better" (Alger, 1985: 187), although "there comes a time - when a man passes forty when he sets as higher value on the comforts of life" (Alger, 1985: 187). Thus, Roland implicitly unveils it is at youth that young men need to work and prosper so as to be repaid in adulthood and old age. It is also through Roland's action that Luke travels to New York to accompany him to visit his unhealthy eight-year-old daughter. It is in the city that Roland provides Luke with new clothes and a watch. In exchange, Luke takes Roland's daughter to Groveton, where his mother will take care of the sick child.

Back in the village, it is discovered that the tin box missing belongs to an important financer, Mr.Amstrong, who soon returns to the village to reclaim the 
contents of his box. Luke finds in Mr. Amstrong a new benefactor figure that immediately sympathises with the young Luke as he reminds him of himself when he was a young boy. As Mr. Amstrong states,

when I was a boy of thirteen and fourteen I ran around in overalls and bare-footed. But I don't think it did me any harm [...] It kept me from squandering money on foolish pleasures, for I had none to spend; it made me industrious and self-reliant, and when I obtained employment it made me anxious to please my employer. (Alger, 1985: 207)

Becoming gradually aware of Luke's honesty and capacity for work, the capitalist Mr Amstrong decides to give him "a chance to rise" (Alger, 1985: 214). Meanwhile, Mr Duncan dreads the interview with Mr Amstrong as regards his carelessness with his tin box, while his son Randolph begins to frequent dissolute places, giving free vent to his extravagant habits, drinking and playing billiards.

With two wealthy benefactors, Roland Reed and Mr Amstrong, Luke's prospects begin to look decidedly bright. In addition to their advice and instruction, a young boy is also required to travel in order to come of age. Urged by Roland Reed, Luke engages in a long trip to Boston in order to find Mr Amstrong's former clerk, Mr Harding, and by extension, the registration number of the government bonds contained in his missing tin box. As stated, Luke enjoys "the prospect of it, having always longed to travel and see distant places" (Alger, 1985: 226). Adventurous and resolute conduct are highly praised in the path towards manhood. Common sense and wittiness to detect conmen are also of primary importance. Through his journey, Luke meets Coleman, a young man who pretends to work for an important company but whose sole purpose is to deceive Luke. Nevertheless, Luke proves bright enough to disentangle himself from him as soon as he becomes aware of Coleman's intentions. In his way to find Mr Harding, Luke travels by train, where he becomes acquainted with different social characters such as a colonel, a missionary and a dude. When he is asked about the reason for his journey, Luke replies he hopes to make some money, and adds "I suppose that is what we are all after" (Alger, 1985: 251). Thus, Luke begins to engage in the capitalist society once he has been initiated by his capitalist benefactors. Despite his youth, Luke's courageous reaction proves crucial when two robbers get into the train, and he actively engages in preventing their wicked aims. Finally, after all his adventures, Luke manages to find Mr Harding, who kindly facilitates the list of the numbers of the bonds that were stolen. Once his job has been completed, Luke goes back to Groveton to receive Mr Amstrong's praise and generous economic reward for his services. Honesty, hard work, persistence, optimism, humility, together with good fortune and prosperous benefactors, are often the values that characterise most of Horatio Alger's heroes. Luke's effort and labour finds retribution when he rises to a comfortable social position. By contrast, Randolph Duncan, the conceited son of the bank manager, finds it was his own father who robbed Mr Amstrong's tin box. Duncan is compelled to resign his position as president of the bank. As a consequence, he and his family had to 
abandon Groveton and "adopt a very different style of living" (Alger, 1985: 279). Due to their precarious situation, even his son Randolph was obligated to work as an office boy and was in no position to boast any longer. By contrast, after Luke's proved value, it is unveiled that Roland Reed was a cousin of late Mr Larkin, Luke's father, who resolves to "make over to him [Luke] ten thousand dollars" (Alger, 1985: 279) and become Luke's guardian. Thus, honest enterprising boys are rewarded, and corrupt wealthy men are punished. Horatio Alger, in a passage that draws the novel to a close, briefly outlines Luke's rise from rags to riches claiming

\begin{abstract}
So closes an eventful passage in the life of Luke Larkin. He has struggled upward from a boyhood of privation and self-denial into a youth and manhood of prosperity and honor. There has been some luck about it, I admit, but after all he is indebted for most of his good fortune to his own good qualities. (Alger, 1985: 280)
\end{abstract}

From this passage it is assumed that Luke's prosperity is basically economic and has often been the result of providence. However, it is also conceded that Luke deserts his good luck since he exemplifies the values all young men should imitate so as to attain success in life, and struggles to become a selfmade man. Actually, in the Horatio Alger 'rags-to-riches' myth, which often finds its reflection on real-life, "many of their subjects had experienced childhood poverty and disrupted family lives which stimulated strong motivations for personal achievement" (Sarachek, 1978: 439).

Through Bulwer-Lytton's Pelham and Horatio Alger's Struggling Upward, which depict the coming of age of a young dandy and a self-made man, young readers are presented with the values that characterise their respective cultures at the time. Henry Pelham comes of age through his family values, academic instruction and his coming out in society (Mitchell, 2003: 87-107). Being born noble, the emerging changes in society, which urge to adopt a more practical view than merely trusting one's origins, are reflected on the evolution of his character (Cronin, 2004: 38-53; King and Engel, 1981: 277-295). His concern about appearances and the establishment of profitable social relations are gradually transformed through the arising importance of integrity and moral instruction. The continuity of the British aristocratic regime depended on birth, while the emerging middle class menaced to discredit their inherited noble authority. Gradually, the aristocrat gave way to the dandy, a decadent figure that struggled to maintain his tantalising position in society. In Horatio Alger's novel, Luke's coming of age is reified through his arising career as an enterprising capitalist once he is initiated by adult benefactors; his independence as an adult is reflected on his prosperous economic situation. In America, capitalism and individual initiative were highly praised. Nevertheless, the young boys who finally manage to rise from their humble origins are those who sacrifice and stick to a moral and honest way of life. In Horatio Alger's novels, the young heroes never become millionaires, but they rise to a comfortable economic position as a reward for their efforts, moving from a rural background towards an urban and capitalist way of life. 
Despite the acknowledged differences between Henry Pelham and Luke Larkin, as a reflection of the idiosyncrasies of their respective cultures, they also bear some resemblance once they approach their adulthood. Henry acknowledges the importance of social respectability and appearances. However, he also values formation and instruction, and it is implied he succeeds in society due to his personal values. By contrast, although Luke Larkin is resourceful and independent, he is initiated in the capitalist world by adult benefactors and acquaintances. Thus, although the success of young men in English narratives depends on their competence to gain the favours of society, their individual values are also taken into consideration, and similarly, in Horatio Alger's narratives, although the young hero is an enterprising individual, capable of becoming a self-made man, he is always helped by adults in a privileged position. It is the balance between moral integrity and social relations that leads them to rise in the social scale, despite their differing origins and respective cultures. Thus, through the reading of these narratives, young English and American boys became acquainted with the ethics, the morals and the ideals more highly praised in nineteenth-century England and America. It is through these narratives that a poetics of success was being constructed in the form of didactic guides to inculcate young readers the cultural and socially-sanctioned values of the time.

\section{BIBLIOGRAPHY}

ALGER, H., JR. ([1890] 1985): Ragged Dick and Struggling Upward, New York, The Penguin American Library.

BARNEY, W. (ed.) (2006): A Companion to 19th-Century America, Oxford, Blackwell.

BAYM, N. (ed.) (1999): The Norton Anthology of American Literature, London and New York, Norton.

BODE, C. (1985): "Introduction", in Ragged Dick and Struggling Upward, New York, The Penguin American Library, (1985): ix-xxi.

BULWER-LYTTON, E.G. ([1828] 1848): Pelham; or, The Adventures of a Gentleman, London, Chapman and Hall.

CAMPBELL, J. L. (1986): “Bulwer's Byronic Apprenticeship and His Early Novels, 1820-29", Edward Bulwer-Lytton, Boston, Twayne (1986): 22-37.

CHRISTENSEN, A.C. (ed.) (2004): The Subverting Vision of Bulwer-Lytton: Bicentenary Reflections, Newark, University of Delaware Press.

CRONIN, R. (2004): "Bulwer, Carlyle, and the Fashionable Novel", The Subverting Vision of Bulwer-Lytton: Bicentenary Reflections, in Allan Conrad Christensen (ed.) (2004): 38-53.

ENGERMAN, S. L. and R. E. GALLMAN (2006): “The Emergence of a Market Economy before 1860", in William L. Barney (ed.) (2006): 121-138.

FRANKLIN, B. (1999): “The Autobiography", in Nina Baym (ed.) (1999): 223-285.

GLICK, E. (2001): “The Dialectics of Dandyism”, Cultural Critique, 48: 129-163.

GOLDFARB, R.M. (1962): "Late Victorian Decadence", The Journal of Aesthetics and Art Criticism, 20:4: 369-373.

HUGUES, W. (1992): "Silver Fork Writers and Readers: Social Contexts of a Best Seller", NOVEL: A Forum on Fiction, 25: 3: 328-347. 
KING, M.F. and E. ENGEL (1981): “The Emergian Carlylean Hero in Bulwer's Novels of the 1830s", Nineteenth-Century Fiction, 36:3: 277-295.

LANE, C. (1994): "The Drama of the Impostor: Dandyism and Its Double", Cultural Critique, 28: 29-52.

MITCHELL, L. (2003): "Society", Bulwer Lytton: The Rise and Fall of a Victorian Man of Letters, London and New York, Hambledon and London (2003): 87-107.

OAKLEY, J.W. (1992): "The Reform of Honor in Bulwer's Pelham", Nineteenth-Century Literature, 47:1: 49-71.

PITOFSKY, A. (1998): “Dreiser's The Financier and the Horatio Alger Myth", Twentieth Century Literature, 44:3: 276-290.

ROSSBACH, S. (1999): "Dandyism in the Literary Works of Barbey d'Aurevilly: Ideology, Gender, and Narration", Modern Language Studies, 29: 1: 81-102.

SAISSELIN, R. G. (1956): "Dandyism and Honnetete", The French Review, 29:6: 457-460.

SARACHEK, B. (1978): "American Entrepeneurs and the Horatio Alger Myth", The Journal of Economic History, 38:2: 439-456.

SPENCE SMITH, T. (1974): "Aestheticism and Social Structure: Style and Social Network in the Dandy Life", American Sociological Review, 39: 5: 725-743.

TUCKER, H.F. (ed.) (2005): A Companion to Victorian Literature and Culture, Oxford, Blackwell.

VANDEN BOSSCHE, C. R. (2005): “Moving Out: Adolescence”, in H.F. Tucker (ed.) (2005): 82-96.

ZUCKERMAN, M. (1972): “The Nursery Tales of Horatio Alger", American Quaterly, 24:2: 191-209. 